\title{
RET Inhibitor
}

National Cancer Institute

\section{Source}

National Cancer Institute. RET Inhibitor. NCI Thesaurus. Code C159438.

Any agent that inhibits the receptor tyrosine kinase rearrang ed during transfection (RET). 